\title{
PENGEMBANGAN APLIKASI UNTUK PEMANTAUAN DAN EVALUASI PENDIDIKAN ANAK USIA DINI
}

\section{APPLICATION DEVELOPMENT FOR MONITORING AND EVALUATION OF EARLY CHILDREN EDUCATION}

\author{
Sudirman \\ Program Studi Pendidikan Matematika, Universitas Qamarul Huda Badaruddin Bagu, Lombok Tengah, \\ Nusa Tenggara Barat, Indonesia
}

Informasi Artikel

Article History:

Submission: 29-11-2020

Revised: 19-12-2020

Accepted: 21-12-2020

\section{Kata Kunci:}

Aplikasi seluler, Pemantauan, Evaluasi, Pendidikan Anak, Perkembangan Anak

\section{Keywords:}

Mobile applications, Monitoring, Evaluation, Child Education, Child Development.

\section{* Korespondensi:}

sudirman@uniqhba.ac.id

\begin{abstract}
Abstrak
Studi ini melaporkan tahapan proses pengembangan aplikasi seluler untuk sistem manajemen informasi data real-time untuk pemantauan dan evaluasi pendidikan dan pertumbuhan anak usia dini, aplikasi ini juga dapat melacak dan membantu guru atau petugas lapangan lainnya dalam memantau dan mengevaluasi tentang layanan anak usia dini. Metode pengumpulan data melalui pemetaan, wawancara mendalam dengan pemangku kepentingan, tinjauan dokumen, pengembangan aplikasi, mengentri data langsung di lapangan menggunakan aplikasi seluler, pengujian dan analisis aplikasi yang dilakukan pada 145 anak di Kecamatan Pringgarata, Lombok Tengah. Gambaran lengkap tentang pendidikan dan perkembangan anak usia dini ini dipetakan dan dihubungkan dalam satu aplikasi berbasis android yang secara sistematis menampilkan data individu maupun kelompok (misalnya profil sekolah) di berbagai aspek kehidupan pendidikan anak usia dini. Data dapat dengan mudah diakses kapan saja oleh pihak yang berwenang menggunakan tablet PC atau ponsel, pada wilayah yang koneksi internetnya belum tersedia karena infrastruktur jaringan belum memadai, sistem ini juga memungkinkan penyimpanan keamanan secara offline yang dapat secara otomatis terhubung ke server ketika koneksi jaringan tersedia. Pengentrian data secara langsung menggunakan tablet $\mathrm{PC} /$ ponsel akan terprogram dan terhubung pada dashboard laporan yang dapat diakses oleh pemangku kepentingan terkait di setiap tingkatan. Untuk menghindari penyalahgunaan data, akses tersebut akan dibatasi dengan sistem login yang aman. Berdasarkan hasil penelitian, aplikasi ini mudah digunakan untuk pemantauan dan evaluasi secara real time tentang pendidikan dan perkembangan anak usia dini.
\end{abstract}

\begin{tabular}{l} 
Abstract \\
\hline This study reports the stages of the process of developing a mobile \\
application for a real-time data management system for monitoring and \\
evaluating early childhood education and growth, this application can \\
also track and assist teachers or other field workers in monitoring and \\
evaluating early childhood services. Methods of collecting data through \\
\hline
\end{tabular}


mapping, in-depth interviews with stakeholders, reviewing documents, developing applications, entering data directly in the field using a mobile application, testing and analyzing applications were carried out on 145 children in Pringgarata District, Central Lombok. This complete picture of early childhood education and development is mapped and linked in an android-based application that systematically displays individual and group data (for example school profiles) in various aspects of early childhood education life. Data can be easily accessed at any time by the authorities using a tablet PC or mobile phone, in areas where the internet connection is not yet available due to inadequate network infrastructure, this system also allows offline security storage that can automatically connect to the server when a network connection is available. Direct data entry using a tablet $P C /$ mobile will be programmed and connected to a reporting dashboard that can be accessed by relevant stakeholders at every level. To avoid misuse of data, this access will be restricted by a secure login system. Based on research results, this application is easy to use for monitoring and evaluation in real-time about early childhood education and development

\section{PENDAHULUAN}

Banyak pekerja lapangan yang menggunakan pencatatan dengan kertas mengeluh bahwa menyusun laporan bulanan dan tahunan secara manual untuk supervisor mereka membutuhkan lebih banyak waktu daripada yang seharusnya. Selain itu, supervisor mengeluh bahwa laporan yang mereka terima dari pekerja tidak lengkap atau tidak terkompilasi dengan baik[1]. Salah satu manfaat beralih ke sistem pencatatan tanpa kertas adalah kemampuan untuk mengotomatiskan dan menstandarkan pelaporan di semua tingkatan di lapangan[2]. Data yang dimasukkan dapat secara otomatis disinkronkan dengan modul pelaporan, sehingga pekerja dapat mengakses dan menyusun laporan mereka kapan saja. Mereka dapat dengan mudah melacak kemajuan mereka setiap bulan atau tahun tanpa harus mengumpulkan data secara manual.

Pengawas dan otoritas pelaporan dapat yakin bahwa data yang dilaporkan akurat dan mencerminkan penyediaan layanan pendidikan di lapangan. Mereka dapat dengan mudah mendeteksi anomali dengan pelaporan digital dan secara signifikan mengurangi waktu untuk menanggapi keadaan darurat, seperti pandemic Covid yang saat ini sedang terjadi[2]. Di daerah pedesaan, atau di manapun petugas lapangan pendidikan yang mungkin tersebar dan sulit dijangkau, akan memudahkan pekerjaan mereka jika memiliki portal web online dan dasbor untuk pemantauan pelayanan pendidikan dan perkembangan anak secara harian, cara ini akan mengefisienkan dan memastikan petugas secara teratur memberikan pelayanan tepat waktu [3].

Penyediaan portal web memungkinkan petugas di level yang lebih tinggi untuk memantau data anak dan mencetak laporan pada saat diperlukan setiap bulan atau setiap tahun. Pada level Kepala Bidang atau Kepala Dinas Pendidikan dapat login untuk memantau petugas lapangan atau guru mereka dan melihat penyediaan layanan mereka secara real time di tingkat lapangan, selain itu juga dengan adanya backup server untuk mengarsipkan data akan memudahkan petugas lapangan untuk meninjau kembali data lama yang tidak lagi disimpan di aplikasi[4].

\section{METODE}

Metodologi pengembangan aplikasi ini. 
PENGEMBANGAN APLIKASI UNTUK PEMANTAUAN DAN EVALUASI PENDIDIKAN ANAK USIA DINI

\subsection{Telaah Literatur.}

Pengumpulan data dari buku, literatur, atau objek yang berkaitan dengan topik Perawatan Anak termasuk modul Community Development Workers diterbitkan oleh Bank Dunia dan Mitra pada tahun 2013. Algoritma penghitungan antropometri dengan Z Score. untuk klasifikasinya menggunakan tabel kalkulasi dari "buku antropometri 2010" dari kementerian kesehatan Indonesia dan untuk indikator bobot menggunakan standar garis batas merah [19].

\subsection{Hardware dan Software.}

Aplikasi pengasuhan anak terdiri dari dua sistem aplikasi yaitu Application Server yang menyimpan data keseluruhan dari aplikasi klien yang hanya berisi data berdasarkan cakupan area pengembangan masyarakat di lapangan. Server bertanggung jawab atas permintaan untuk data yang sudah ada dan yang baru. Tool yang digunakan untuk membangun sistem informasi berbasis mobile android adalah pemrograman Java dan MySQL. IDE Android Studio adalah Integrated Development Environment (IDE) resmi untuk pengembangan aplikasi Android, berdasarkan Intellij IDEA.

\subsection{Spesifikasi Hardware.}

a. Server.

Aplikasi ini membutuhkan spesifikasi server sebagai berikut: Server Virtual Produk/Layanan-VPS Hazelnut Aktif, Kuota Cadangan 10 x GB, Template OS adalah debian-8.0x86_64, Platform Linux x86_64, Paket OS Debian GNU / Linux 8.0 (untuk AMD64 / Intel EM64T) Template OS EZ, CPU Core 4, Batas CPU 1600 MHz, Memori 4,00 GB, HDD 80,0 B.

b. Klien.

Spesifikasi klien sebagai berikut: Ukuran layar 5 ", Merek Samsung Galaxy, OS Android 6.0, RAM 2 GB, Storage 16B.

c. Laptop.

Spesifikasi Laptop adalah Merk Lenovo, Type Legion Y520-N21D, Processor Intel Core i77700HQ, RAM 16GB DDR4; 2 x SODIMM Slot, HDD 1TB SATA SSD + 256GB, VGA menggunakan NVIDIA®GeForce ${ }^{\circledR G T X} 1050$ Ti, DVD Writer, Layar 15.6 ", DOS.

d. Web server: Nginx.

\subsection{Prosedur pengembangan aplikasi.}

Perancangan aplikasi dilakukan dengan merancang desain UI (User Interface), database seperti variabel/field, nilai, label, pemeriksaan logika, pemeriksaan jarak, perhitungan dan desain fungsi pada aplikasi.

a. Logika.

Staf use case menggambarkan interaksi antara guru dan sistem. Tutor/guru diwajibkan untuk masuk untuk memastikan akses ke data. Login menggunakan username dan password untuk setiap tutor. Username dan Password akan dikirim ke server untuk validasi. Server yang menerima data dari aplikasi mendeteksi setiap permintaan berdasarkan alamat URL yang diterimanya. Data dari alamat URL ini akan menentukan jenis permintaan yang harus dilakukan server pada saat yang sama menanggapi permintaan dengan data yang sesuai. Apabila terdapat kesesuaian dengan data pengguna yang ada maka akan dibalas berupa data dasar dari pengguna dan data berupa kode hak akses.

Data dasar yang dikirimkan kembali ke klien nama lengkap, NIK, lokasi meliputi nama Kecamatan, Kabupaten dan Provinsi setelah berhasil login, hal pertama yang harus dilakukan adalah mengisi database lokal dengan meminta server mengirim data berdasarkan lokasi area 
kerja petugas. Setelah data awal terisi maka dapat dilakukan kegiatan pencatatan data kunjungan ke pelayanan pendidikan anak. Data dari server ini sebagai data dasar yang digunakan untuk aplikasi identitas ibu dan anak pada aplikasi pendidikan anak.

b. Aktivitas.

Aktivitas menggambarkan aktivitas dalam sistem yang telah dibangun, bagaimana setiap aliran dimulai, keputusan yang mungkin terjadi, dan bagaimana akhirnya. Diagram aktivitas juga dapat menggambarkan proses paralel yang mungkin terjadi dalam beberapa eksekusi. Diagram aktivitas terdiri dari proses login staf dan proses manajemen data master.

c. Kelas.

Kelas menggambarkan keadaan (atribut atau properti) dari suatu sistem, sekaligus menawarkan layanan untuk memanipulasi situasi (metode atau fungsi). Kelas adalah spesifikasi yang jika dipakai akan menghasilkan suatu objek dan merupakan inti dari pengembangan dan desain berorientasi objek.

d. Database SQLite.

Perancangan database merupakan terjemahan dari diagram kelas dalam bentuk tabel yang berisi nama variable or field, tipe field, tipe kunci, dan aksi field. Database untuk penyimpanan data pada aplikasi ini, yang berguna untuk menampung data yang dibutuhkan.

e. UIX.

Berdasarkan Kasus penggunaan dan diagram alur. Setiap elemen memecah menjadi penyampaian dan meletakkan strategi untuk melanjutkan. Rancang bagian dari (UI atau UX) dan persiapkan desain yang memberikan pengalaman pengguna terbaik. Prototipe UI diuji pada perangkat yang berbeda. Kami memastikan kelancaran navigasi di Aplikasi Seluler yang sudah dibuat.

\subsection{Pemrograman aplikasi.}

Pengembangan aplikasi seluler ini menggunakan Model View Presenter (MVP) yang merupakan pola arsitektur Android terbaru dan terbaik. Ini memisahkan logika bisnis (Model) dari logika tampilan (Aktivitas atau Fragmen) dengan memanfaatkan langkah perantara yang disebut Presenter.

a. Tampilan.

Tampilan sangat terbatas di MVP, ini hanya berfungsi pada data tampilan dan menavigasi ke layar baru saat penyaji menyuruhnya. Tampilan tidak memiliki visibilitas model, kecuali POJO atau Entitas. Berkenaan dengan android secara khusus, ini akan mencakup Activity, Fragments, Recycler View Adapters, dan apa pun yang memperluas kelas android View. Preferensi penulis adalah membiarkan aktivitas dan fragmen berbicara dengan penyaji dan membiarkan tampilan dan adaptor hanya menampilkan data dan mendelegasikan acara (Saat Di klik) kembali ke aktivitas atau fragmen.

b. Presenter.

Presenter terletak di antara tampilan dan model, dan berfungsi untuk peristiwa yang diteruskan dari tampilan. Misalnya, ketika tombol Selesai (untuk menyimpan data) di klik di dalam tampilan, itu akan memanggil presenter. Simpan (). Setelah ini terjadi, penyaji menggunakan model untuk menentukan apakah semua kriteria terpenuhi (yaitu alamat email yang valid) dan jika demikian, kami dapat menyimpan data dengan aman. Penyaji kemudian akan memberitahu tampilan untuk menampilkan pesan kesalahan, atau memberitahu tampilan untuk mengarahkan dalam hal perbaikan.

c. Model.

Model ini mencakup logika bisnis yang sepenuhnya dipisahkan dari logika khusus UI atau Platform. Ini mencakup Entitas, layanan atau pembantu backend (web, database, dll), dan logika 
bisnis. Ini akan menggunakan kelas pembungkus (disebut model atau Interactor) yang akan berbicara langsung ke layanan backend dan memegang logika bisnis.

2.6 Perhitungan Z score.

a. Sumber Data.

$Z$ score merupakan indikator grafik pertumbuhan yang dapat diunduh di http://who.int/childgrowth/standards/ pada file yang berisi persentil Z score. File tersebut berisi koefisien L, M dan S yang dapat digunakan untuk menghitung Z Score.

b. Perhitungan.

Alur proses penghitungan sebagai berikut, aplikasi akan menyiapkan semua indikator menjadi array 2 dimensi dengan masing-masing 4 kolom, berisi usia, nilai L, M dan S, pengguna memasukkan data tanggal kunjungan anak, berat dan panjang atau tinggi ke dalam aplikasi, aplikasi hitung usia anak-anak saat ini pada unit hari, dengan menemukan kisaran antara tanggal kunjungan dan tanggal lahir anak. Dengan menggunakan umur (hasil perhitungan pada langkah b) sebagai indeks, aplikasi akan mendapatkan data L, M dan S pada indeks tersebut dan menghitung Z Score menggunakan rumus LMS yang dijelaskan pada gambar 1.

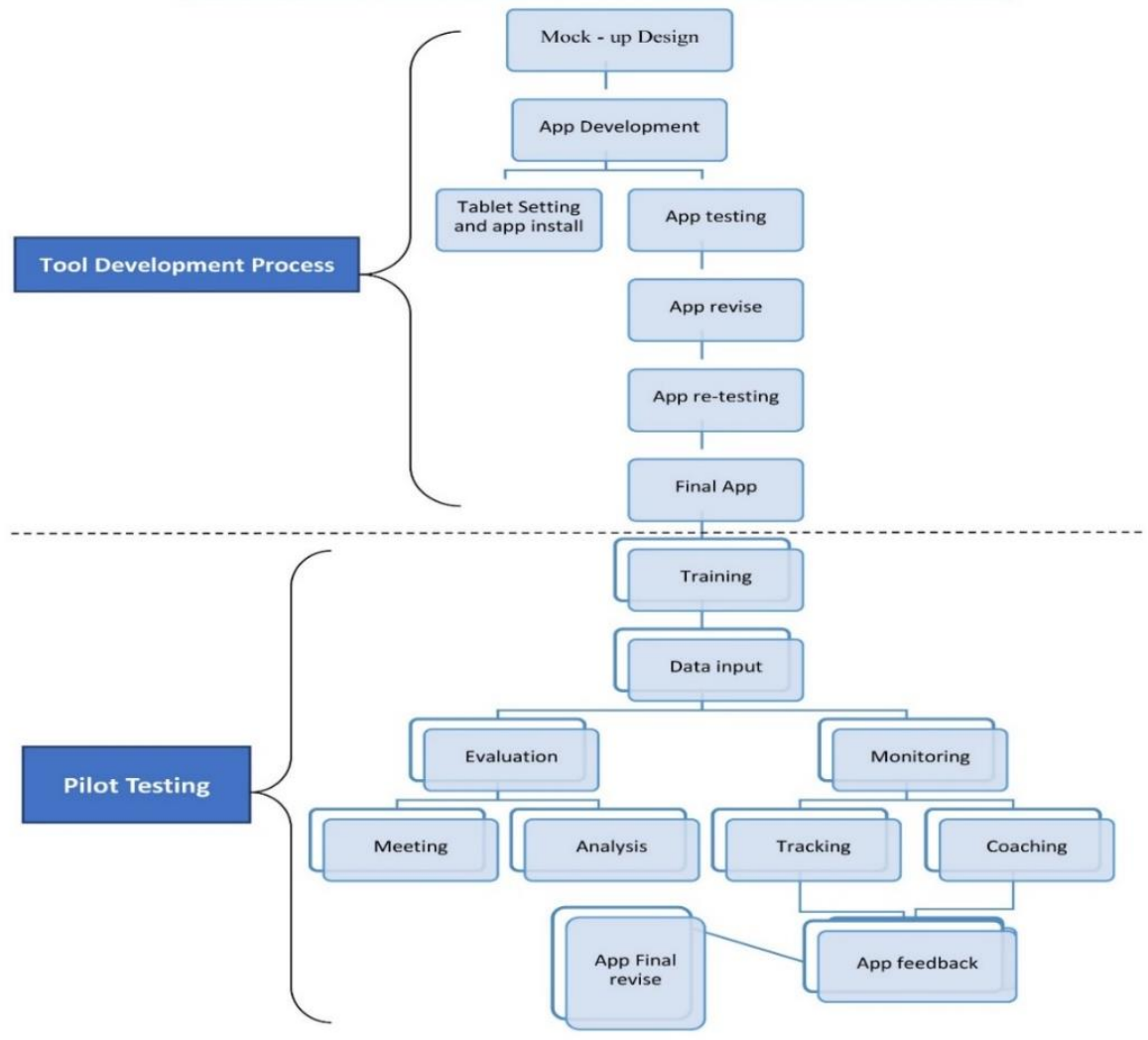

Gambar 1. Alur pengembangan aplikasi

$Z_{\text {ind }}=\frac{\left[\frac{y}{M(t)}\right]^{L(t)}-1}{S(t) L(t)}$

Antropometri memiliki algoritma penghitungan yang sama dengan Z Score. Untuk klasifikasinya menggunakan tabel kalkulasi dari buku antropometri Kementerian Kesehatan RI.

2.7 Alur pengembangan aplikasi dan uji coba.

Tahapan untuk pembuatan, pengembangan dan pengujian fungsionalitas aplikasi yang 
telah dikembangkan seperti terlihat pada gambar 1.

\section{HASIL DAN PEMBAHASAN.}

Untuk mendapatkan gambaran lengkap tentang pendidikan dan pertumbuhan pada anak usia dini, data tentang pertumbuhan dan pendidikan anak harus dipetakan dan dihubungkan secara terintegrasi dalam satu aplikasi. Penelitian ini memperkenalkan aplikasi seluler untuk secara sistematis mengumpulkan data individu maupun kelompok (misalnya data sekolah) di berbagai aspek kehidupan anak, mulai dari Pengasuhan anak, kesehatan dan pendidikan. Menggunakan tablet PC atau ponsel, data dapat dengan mudah dimasukkan secara real time oleh pengguna[5]. Data dapat dengan mudah diakses kapan saja oleh pihak yang berwenang menggunakan tablet PC atau ponsel, pada wilayah yang koneksi internetnya belum tersedia karena infrastruktur jaringan belum memadai, sistem ini juga memungkinkan penyimpanan keamanan secara offline yang dapat secara otomatis terhubung ke server ketika koneksi jaringan tersedia. Pengentrian data secara langsung menggunakan tablet PC/ponsel akan terprogram dan terhubung pada dashboard laporan yang dapat diakses oleh pemangku kepentingan terkait di setiap tingkatan. Untuk menghindari penyalahgunaan data, akses tersebut akan dibatasi dengan sistem login yang aman [6].

Berdasarkan studi ini, formulir untuk menginput data tentang pendidikan dan pertumbuhan anak dapat dengan mudah ditampilkan dalam layar register pintar dengan mengetuk tombol, dan memungkinkan entri data offline di mana koneksi jaringan tidak selalu tersedia. Data telah disimpan dengan aman secara offline sampai perangkat memiliki koneksi jaringan lagi dan data tersebut kemudian dikirim ke server yang aman [7]. Ada server cadangan yang disediakan untuk menjaga data diperbarui dan dapat diakses jika server utama mendapat masalah. Dengan aplikasi ini, pengguna dapat dengan mudah beralih di antara pertanyaan, menjawabnya dalam urutan mana yang paling cocok dengan alur kerja mereka. Aplikasi ini tersedia algoritma yang memungkinkan untuk validasi entri data pada saat entri data berlangsung sehingga jika ada kesalahan entri, secara otomatis akan muncul pesan error dan aplikasi ini juga memungkikan untuk mengharuskan mengisi variabel atau field yang wajib diisi jika termasuk pertanyaan yang required (diwajibkan untuk diisi). Hal ini untuk menghindari data missing karena terlompati pada waktu entry data [8].

Selain itu, hasil penelitian menunjukkan aplikasi ini menawarkan fitur-fitur canggih seperti kalkulasi hasil entri yang berguna dalam formulir di mana pengguna harus memilih lokasinya dari daftar yang panjang. Aplikasi ini juga menyediakan secara cerdas fitur-fitur yang memudahkan pengguna dapat menyelesaikan proses entri menjadi lebih cepat. Seperti rangkaian pilihan pengurutan dan filter yang dapat disesuaikan untuk mengatur ulang dan memfilter daftar anak ke daftar baru yang sesuai dengan kebutuhan pengguna. Setiap daftar dilengkapi dengan fitur pencarian pintar, hal ini untuk menghindari pengguna untuk mencari nama anak satu persatu yang tentunya akan menyita waktu. Fitur pencarian juga dapat disesuaikan dengan istilah pencarian apa pun yang dibutuhkan, baik nama atau nomor ID [9]. Aplikasi ini memungkinkan entri data antarmuka. Data dikumpulkan langsung menggunakan aplikasi, untuk mengurangi kesalahan pengetikan, aplikasi ini menyediakan algoritma untuk memeriksa konsistensi dan validitas data pada saat entri data berlangsung. Jika ditemukan error atau inkonsistensi maka akan langsung diperbaiki. Setelah semua data masuk ke server, selanjutnya harus diedit dan dibersihkan sebelum dianalisis.

Data yang dimasukkan secara otomatis disinkronkan dengan modul pelaporan, sehingga guru atau pekerja lapangan anak dapat mengakses laporan mereka kapan saja. Mereka dapat 
dengan mudah melacak kemajuan perkembangan dan pendidikan anak tanpa harus setiap kali mengumpulkan data secara manual. Pengawas pada level yang lebih tinggi dan otoritas bidang pelaporan yakin bahwa data yang dilaporkan akurat dan mencerminkan penyediaan layanan nyata pendidikan di lapangan [10]. Pendidikan Anak Usia Dini (PAUD) biasanya berada di daerah pedesaan, atau lokasi petugas lapangan pendidikan atau pengembangan komunitas mungkin tersebar dan sulit dijangkau, melalui penelitian ini tersedia portal web dan dasbor online untuk memantau perkembangan harian, hal ini merupakan cara yang efisien dan cerdas untuk memastikan petugas secara teratur memberikan pelayanan tepat waktu. Portal web registry memungkinkan kepala dinas atau berada pada level yang paling tinggi telah disediakan user dan password masing-masing sehingga dapat mengakses dengan cara login pada setiap saat untuk memantau kemajuan data dan mencetak laporan yang sangat diperlukan pada periode tertentu baik bulanan atau tahunan. Pengawas di tingkat yang lebih tinggi dapat login untuk memantau perkembangan dan penyediaan anak secara real time. Portal web juga dapat menyimpan data untuk diarsipkan, data anak bisa di cek kembali jika data anak tersebut tidak lagi disimpan di aplikasi karena telah di back up dalam server backend dan klien ponsel berbasis Android [11][12].

Server telah disimpan di lokasi yang memiliki konektivitas yang tinggi, tenaga ahli komputer disediakan untuk memelihara dan back up data setiap hari di server. Operator yang terpilih memiliki kemampuan dan keterampilan untuk memantau, mengelola dan memelihara server atau manajemen server [13]. Semua akses data baik masuk maupun keluar harus sepengetahuan supervisor. Pemanfaatan data untuk semua pemangku kepentingan atau orang lain dapat diakses melalui satu pintu (berbasis website) Melalui login yang aman, pengguna dapat mengakses data untuk analisis dan pelaporan [14]. Data dalam database atau dalam paket statistik telah dibatasi untuk mereka yang memiliki kata sandi untuk akses, data untuk keperluan laporan atau publikasi, harus dijaga kerahasiaannya. Data yang dikumpulkan selama studi adalah pengolahan data secara real-time dan langsung ditransfer ke server. Hanya personel terbatas yang memiliki izin untuk mengakses data sesuai kebutuhan. Pemeriksaan data setiap hari seperti validitas dan konsistensi internal dengan script pemrosesan data otomatis telah tersedia secara otomatis dalam aplikasi dan server, jika ada data yang tidak konsisten maka secara realtime akan memberikan pesan atau memperingatkan supervisor tentang potensi masalah yang memerlukan koreksi.

\section{SIMPULAN}

Berdasarkan hasil dan pembahasan penelitian, aplikasi ini mudah diterapkan untuk pemantauan dan evaluasi secara real-time tentang pendidikan dan perkembangan anak usia dini.

\section{REFERENSI}

[1] A. Abubakar, P. Holding, F. Van De Vijver, G. Bomu, and A. Van Baar, "Developmental monitoring using caregiver reports in a resource-limited setting: The case of Kilifi, Kenya," Acta Paediatr. Int. J. Paediatr., vol. 99, no. 2, pp. 291-297, 2010.

[2] Y. Self-reports, "Child Behavior Checklist 6-18," Encycl. Autism Spectr. Disord., no. August, pp. 581-581, 2013.

[3] L. G. Weiss, T. Oakland, and G. P. Aylward, "Bayley-III Clinical Use and Interpretation," Bayley-III Clin. Use Interpret., 2010.

[4] H. McConachie et al., "Systematic review of tools to measure outcomes for young children 
with autism spectrum disorder," Health Technol. Assess. (Rockv)., vol. 19, no. 41, pp. 1538, 2015.

[5] M. N. Kooijman et al., "The Generation R Study: design and cohort update 2017," Eur. J. Epidemiol., vol. 31, no. 12, pp. 1243-1264, 2016.

[6] E. C. Care and S. Africa, Africa 's Future, Africa's Challenge. .

[7] F. Lejeune, C. B. Tolsa, M. B. Graz, P. S. Hüppi, and K. Barisnikov, "Emotion, attention, and effortful control in 24-month-old very preterm and full-term children," Annee Psychol., vol. 115, no. 2, pp. 241-264, 2015.

[8] A. Lavallée, M. Aita, J. Côté, L. Bell, and T. M. Luu, "A guided participation nursing intervention to theraupeutic positioning and care (GP_Posit) for mothers of preterm infants: Protocol of a pilot randomized controlled trial," Pilot Feasibility Stud., vol. 6, no. 1, pp. 1-11, 2020.

[9] S. Peacock, S. Konrad, E. Watson, D. Nickel, and N. Muhajarine, "Effectiveness of home visiting programs on child outcomes: A systematic review," BMC Public Health, vol. 13, no. $1,2013$.

[10] J. . Shonkoff and D. A. Philips, From neurons to neighbourhood: science of early childhood development. 2000.

[11] S. Umayah and S. Suyadi, "Pengembangan Kurikulum Berbasis Nusantara dan Internasional di PAUD Fastrack Funschool Yogyakarta," JECED J. Early Child. Educ. Dev., vol. 2, no. 1, pp. 1-12, 2020.

[12] A. N. E. W. Kid and O. N. The, "Ficha 2 artigo 4," no. 6, pp. 243-248, 2005.

[13] The Consultative Group on Early Childhood Care and Development, "A Transformative Solution: Reducing Poverty and Inequality through a Post-2015 Early Childhood Development Goal," 2013.

[14] A. V. Shankar et al., "Programmatic effects of a large-scale multiple-micronutrient supplementation trial in Indonesia: Using community facilitators as intermediaries for behavior change," Food Nutr. Bull., vol. 30, no. 2, pp. 207-214, 2009. 